\title{
Significance of microheterotrophs in the decomposition of phytoplankton: estimates of carbon and nitrogen flow based on the biomass of plankton communities
}

\author{
R. C. Newell and E. A. S. Linley \\ Royal Society Research Group, c/o Institute for Marine \\ Environmental Research, Prospect Place, Plymouth PL1 3DH, England
}

\begin{abstract}
A study of the standing stocks of consumer organisms in waters off the western approaches to the English Channel during late August shows that the microheterotrophic community of protozoans and bacteria comprise as much as $46 \%$ of the total consumer carbon at mixed water station (M), $60 \%$ at frontal station (F) and $21 \%$ at a deeper stratified water station (E5). Values for biomass have been combined with literature values for carbon budgets of representatives of each of the major components of the heterotrophic community to arrive at an estimate of carbon flow through the consumer assemblage as a whole. A depth-integrated carbon supply of 3.1 to $4.9 \mathrm{gC} \mathrm{m}^{-2} \mathrm{~d}^{-1}$ would be required to sustain the consumer community if all components were actively heterotrophic. An average gross primary production of $1000 \mathrm{~g} \mathrm{C} \mathrm{m}^{-2} \mathrm{~d}^{-1}$ would be capable of supporting the larger zooplankton and only $17 \%$ of the bacteria in an actively heterotrophic state. In offshore or steady-state situations, therefore, carbon flow through the microheterotrophic community may be considerably lower than might be anticipated from their high biomass and relatively small cell size; this may account for the low values for bacterial production under natural conditions which are commonly reported in the literature. It is suggested that in coastal waters during late summer, heterotrophic activity of a greater proportion of the microheterotrophic community may be supported by consumption of both production and biomass of senescent phytoplankton cells; this may account for the rapid decline and dissipation of carbon at the end of phytoplankton blooms at this time of the year. Under these conditions, as much as 50 to $60 \%$ of total carbon flow is estimated to enter the bacteria, 34 to $41 \%$ being subsequently respired by the bacteria and a further 9 to $12 \%$ by heterotrophic microflagellates. Nitrogen regeneration by the heterotrophic community as a whole during this phase may amount to as much as 2.8 to $5.3 \mathrm{mg} \mathrm{N} \mathrm{m} \mathrm{N}^{-3} \mathrm{~d}^{-1}$ or 63 to $72 \%$ of the nitrogen entering the consumer community. This may be of significance in supporting further primary production after the decomposition phase of phytoplankton blooms in shallow water. The low carbon flow available to support the microheterotrophic community in offshore steady-state situations suggests, however, that nitrogen regeneration by bacteria and protozoans may be of less importance in offshore pelagic waters than in shallow coastal systems.
\end{abstract}

\section{INTRODUCTION}

The relative significance of pathways from primary production to larger herbivores and through the microheterotrophic community of bacteria and protozoans has attracted widespread interest, particularly since the work of Sorokin $(1975,1977,1978,1981)$ and Sieburth et al. (1978) suggested that bacteria may comprise a major proportion of the total biomass of all heterotrophic consumer organisms in the water column. Dagg et al. (1980) estimated, for example, that large copepods harvested less than $5 \%$ of the daily primary production in the Peruvian upwelling system during April 1977. Although Dagg and Cowles (1982) and Paffenhöfer (1982) point out that small copepods play a major role in the community grazing in this region, Sorokin and Mikheev (1979), in a comprehensive study of energy flow through the pelagic community associated with the Peruvian upwelling system as a whole, have estimated that as much as 70 to $80 \%$ of the total energy flux occurs through the microheterotrophic community (bacteria, ciliates and heterotrophic mic- 
roflagellates). Again, Joiris et al. (1982) have made a budget for the cycling of carbon through plankton communities in Belgian waters and have suggested that for coastal waters in general, carbon flow is dominantly through the planktonic and benthic microheterotrophs, rather than through the larger grazing zooplankton.

These conclusions contrast with those reported for oceanic and some shelf waters where primary production by the phytoplankton appears to be insufficient to meet the estimated requirements of the pelagic consumers, especially when the high biomass and small cell size of the microheterotrophic community is taken into account (Sieburth, 1977). In these waters the coupling between primary production and zooplankton grazing is extremely tight, a large proportion of the phytoplankton production during the summer entering the herbivorous zooplankton rather than the microheterotrophic community (Malone and Chervin, 1979; Dagg and Turner, 1982). Falkowski et al. (1983), for example, have constructed a carbon budget for the euphotic zone in the Middle Atlantic Bight and have shown that primary production added $\sim 350 \mathrm{mg}$ $\mathrm{C} \mathrm{m} \mathrm{m}^{-2} \mathrm{~d}^{-1}$ to the POC pool which comprised $\sim 6000 \mathrm{mg} \mathrm{C} \mathrm{m}^{-2}$ of which $\sim 2500 \mathrm{mg} \mathrm{C} \mathrm{m}^{-2}$ or $42 \%$ was phytoplankton carbon. Ingestion by the zooplankton alone removed $\sim 450 \mathrm{mg} \mathrm{C} \mathrm{m}{ }^{-2} \mathrm{~d}^{-1}$ of which $\sim 135 \mathrm{mg} \mathrm{C} \mathrm{m}^{-2} \mathrm{~d}^{-1}$ were returned to the POC pool as faeces. Zooplankton grazing thus somewhat exceeded primary production and net transfer from POC pool to zooplankton was $450-135=315 \mathrm{mg} \mathrm{C} \mathrm{m}^{-2} \mathrm{~d}^{-1}$.

Again, although nitrogen regeneration from the microbial decomposition of sedimented phytoplankton from shallow water sediments is considered to be of importance in the maintenance of primary production in such coastal systems (Rowe et al., 1975; Nixon et al., 1976; Rowe and Smith, 1977; Billen, 1978; Nixon, 1980; Blackburn and Henriksen, 1983; La Roche, 1983), estimates from the Atlantic Ocean suggest that the microbial contribution to regenerated nitrogen is less than might be supposed from their relatively high biomass and small cell size. Walsh et al. (1978; see also Walsh, 1981) constructed an annual nitrogen budget for the Atlantic continental shelf and suggested that approximately $46 \%$ of production is supported by nutrient recycling. Of this, zooplankton were responsible for $38 \%$ of the regenerated nitrogen, benthos $38 \%$ and bacteria only $24 \%$. That is, bacterial remineralisation accounted for only $11 \%$ of the requirements of primary production (see also Smith and Whitledge, 1977). Harrison et al. (1983) have made similar estimates for the outer shelf of the Middle Atlantic Bight in summer and reported that regenerated nitrogen accounted for only $33 \%$ of the total nitrogen requirements of primary production. Of this, zooplankton were responsible for the regeneration of $30 \%$, benthos $7 \%$, microplankton (> $1 \mu \mathrm{m}) 16 \%$, and microplankton $(<1 \mu \mathrm{m}) 47 \%$. That is, although the bacterial component was of more importance in nitrogen regeneration than other size fractions, it nevertheless accounted for only $23 \%$ of the requirements of primary production at this time of the year.

We have recently made a detailed study of the simultaneous standing stocks of the principal components of the pelagic community from bacteria, heterotrophic microflagellates and larger Protozoa to microherbivores (mainly copepod nauplii) and copepods in relation to depth at several stations off the western English Channel during a relatively late stage in the phytoplankton blooms in August 1981 (Holligan et al., 1984a; Linley et al., 1983). Despite the large biomass of the microheterotrophic community of microflagellates, other protozoans and bacteria - compared with larger zooplankton - we have little information on their likely role in the carbon and nitrogen budget of the pelagic community, nor the extent to which the carbon requirements of the heterotrophs could be met by primary production in the water column. The carbon consumption requirements of organisms $<1 \mu \mathrm{m}$ in diameter, for example, may be less than might be supposed on a basis of their biomass and the assumption that they are all actively heterotrophic.

For the Celtic Sea, Joint and Pomeroy (1983) reported very low values for bacterial production and long doubling times of 3 to $54 \mathrm{~d}$ (mean $=13.7 \mathrm{~d}$ ) on the basis of ${ }^{3} \mathrm{H}$-thymidine uptake. They found that heterotrophic bacterial production relative to primary production in the $<1$ to $>0.2 \mu \mathrm{m}$ fraction was on average only $5 \%$ during August. Gieskes et al. (1979) estimated that 20 to $30 \%$ of primary production was in the $<1 \mu \mathrm{m}$ size fraction in the tropical Atlantic, whilst Li et al. (1983) reported a value from 20 to $80 \%$ in this size fraction in the tropical Pacific. Platt et al. (1983) have calculated that $60 \%$ of primary production could be due to small photosynthetic organisms in this size range (see also Waterbury et al., 1979; Johnson and Sieburth, 1979, 1982). Hence, there is now considerable evidence that a significant proportion of primary production is achieved by photoautotrophic organisms of the same size range as bacteria. Recent estimates also suggest that only 10 to $60 \%$ of bacteria are active under natural conditions (for reviews, see S. Y. Newell and Christian, 1981; van Es and Meyer-Reil, 1982) so that their relative role in the heterotrophic utilisation of carbon and in nitrogen regeneration through the pelagic system may be of less importance than would be supposed from estimates of the biomass of assumed heterotrophs in this size range.

This paper reports estimates of carbon and nitrogen flow through heterotrophic communities in mixed, 
frontal and stratified waters off the English Channel, based on the biomass of consumers in the water column combined with literature data for balanced energy budgets obtained from experimental studies on such organisms. The results conform with previous studies for other pelagic communities: in the pelagic system as a whole, a balance between primary production and consumer demands could be sustained if only a relatively small proportion of the microbial biomass were actively heterotrophic (see also Gerlach, 1978; Fuhrman and Azam, 1982; van Es and Meyer-Reil, 1982). During the decomposition phase of a phytoplankton bloom, however, utilisation of both production and biomass of senescent phytoplankton cells by the whole heterotrophic community could result in a rapid decline of the bloom with oxidation of the carbon and regeneration of nitrogen prior to sinking of the detrital material from the water column.

\section{MATERIALS AND METHODS}

\section{Collection of material}

Material was collected over a profile of $60 \mathrm{~m}$ depth at 3 stations in the western approaches to the English Channel between 22.7.81 and 2.8.81 during a cruise aboard the R. V. 'Frederick Russell'. The position of the sampling stations has been described by Holligan et al. (1984a) and Linley et al. (1983) and comprised one station (M) which was representative of mixed waters $\left(49^{\circ} 19^{\prime} \mathrm{N}, 03^{\circ} 15^{\prime} \mathrm{W}\right)$, a second station (F) at the frontal upwelling region $\left(49^{\circ} 19^{\prime} \mathrm{N}, 04^{\circ} 34^{\prime} \mathrm{W}\right)$ and a third station (E5) representative of deeper stratified waters $\left(49^{\circ} 04^{\prime} \mathrm{N}, 06^{\circ} 37^{\prime} \mathrm{W}\right)$. Samples were taken with a submersible pump (Flygt Pumps Ltd., Model B2051) with an average flow rate of $160 \mathrm{I} \mathrm{min}^{-1}$ and whose intake hose of $5 \mathrm{~cm}$ internal diameter was raised at a rate of $2 \mathrm{~m} \mathrm{~min}^{-1}$ from 60 to $2 \mathrm{~m}$. Water from the depth ranges 60 to $48 \mathrm{~m}, 48$ to $36 \mathrm{~m}, 36$ to $24 \mathrm{~m}, 24$ to $12 \mathrm{~m}$ and 12 to $2 \mathrm{~m}$ was then allowed to flow into a series of 5 leached 121 plastic vessels from which samples for subsequent biomass analysis were taken immediately. The remainder of the outflow from the pump was passed through 80 and $200 \mu \mathrm{m}$ mesh nets to collect micro- and meso-zooplankton respectively.

Samples were also collected by a series of up to 10 1.51 NIO bottles over the same range of depths at which pumped samples were taken whilst samples were also taken for mesozooplankton with vertical hauls of a plankton net of $200 \mu \mathrm{m}$ mesh from the sea bed up to $60 \mathrm{~m}$. Estimated values for the biomass of mesozooplankton (mainly copepods) at depths greater than $60 \mathrm{~m}$ based on the average biomass over the depth range 24 to $60 \mathrm{~m}$ were in good agreement with direct counts from vertical plankton hauls. Since no samples of microzooplankton, bacteria and protozoans were made at depths greater than $60 \mathrm{~m}$, their biomass in the water column down to the sea bed was estimated from the mean values over the depth range 24 to $60 \mathrm{~m}$. The depth of the water column was $76 \mathrm{~m}$ at mixed water station (M), $96 \mathrm{~m}$ at $\mathrm{F}$, and $120 \mathrm{~m}$ at stratified $\mathrm{E} 5$. All data expressed per $\mathrm{m}^{3}$ at each depth were then integrated to give values for the entire water column $m^{-2}$ of sea surface.

\section{CHN analysis}

Carbon and nitrogen in the components of the plankton considered were measured with a Carlo-Erba Elemental Analyzer (Model 1106), using cyclohexanone $(10.14 \% \mathrm{~N} ; 51.79 \% \mathrm{C})$ as a standard.

\section{Biomass estimates}

Details of methods of counting and estimation of the biomass of bacteria, phytoplankton and protozooplankton are given by Holligan et al. (1984a) and Linley et al. (1983).

\section{Carbon flow estimates}

The complete carbon flow for the community requires estimates not only of consumption (C), but also of the amount of consumed carbon which is channelled into production (P) or dissipated as respiration (R), faeces (F) and dissolved losses (U) according to the familiar balanced energy equation of Winberg (1956; see Petrusewicz and MacFadyen, 1970):

$$
\mathrm{C}=\mathrm{P}+\mathrm{R}+\mathrm{F}+\mathrm{U}
$$

Assimilation efficiency of the herbivorous zooplankton may be estimated to be $75 \%$ (e.g. Conover, 1966) so that $(\mathrm{F})=0.25 \times \mathrm{C}$. Respiratory losses $(\mathrm{R})$ are taken as $0.50 \times \mathrm{C}$ which gives a yield $(\mathrm{P} / \mathrm{C})$ of 0.25 . Estimates for the components of the balanced energy equation for Protozoa are based on those for Noctiluca miliaris from Dewey (1976) in which $\mathrm{C}=1.139 \times \mathrm{B}_{i} \mathrm{P}=0.337 \times \mathrm{B}$; $\mathrm{R}=0.268 \times \mathrm{B}$. Bacterial production has been estimated assuming a doubling time of approximately $33 \mathrm{~h}$ (or P/B of 1.075 which is half that of actively growing rods in experimental incubation of phytoplankton cell debris (Linley et al., 1983) and close to the mean of all values (1.016) summarised by van Es and Meyer-Reil (1982). Consumption is estimated from a mean value of $\mathrm{P} / 0.31$ derived from experimental estimations of bacterial incorporation of labile components of the photo- 
synthetically produced dissolved organic carbon (PDOC) pool and of structural detrital material (p. 111). Consumption of bactivorous heterotrophic microflagellates is taken as $8.5 \times \mathrm{B}$, and $\mathrm{P}$ is $0.35 \times \mathrm{C}$ (p. 111; Fenchel, 1982d). The sum of carbon losses through both respiration (R) and dissolved materials (U) are obtained by difference.

\section{RESULTS}

\section{Standing stocks of consumers}

The basic partitioning of carbon amongst the standing stocks of consumer organisms in surface waters down to $60 \mathrm{~m}$ depth has recently been described by
Holligan et al. (1984a). In order to estimate potential carbon and nitrogen flow through the consumer community as a whole in relation to primary production in the water column, however, it is necessary to include estimates of consumer biomass and consumption requirements down to the sea bed.

Unfortunately, detailed information of standing stocks is available only for the mesozooplankton (mainly copepods) from depths greater than $60 \mathrm{~m}$. However, some estimates can be made from the average of the biomass of each component in the depth range 24 to $60 \mathrm{~m}$, and when this is applied to mesozooplankton for the water column below $60 \mathrm{~m}$ there is general agreement with results from direct estimates by vertical plankton hauls. These latter values are shown in parentheses in Table 1, together with the

Table 1. Integrated standing stocks of heterotrophs ( $\mathrm{mg} C$ ) for various depth intervals and summed value for the whole water column ( $\mathrm{mg} \mathrm{C} \mathrm{m}^{-2}$ sea surface) at mixed water station (M), frontal station (F) and stratified water station (E5). Values for water from $60 \mathrm{~m}$ to the sea bed are estimated from the average values at 24 to $60 \mathrm{~m}$. Direct counts of mesozooplankton from sea bed to $60 \mathrm{~m}$ by direct vertical hauls and integrated values based on these direct estimates are shown in parentheses. Based partly on Holligan et al. (1984a) and Linley et al. (1983), with additional data on standing stocks of bacterial rods. Nitrogen equivalents calculated from a mean value of 4.39 for the $C: N$ ratio of the zooplankton (Holligan et al., 1984a) and an estimate of 5.0 for bacteria and protozoans (Fenchel and Blackburn, 1979)

\begin{tabular}{|c|c|c|c|c|c|c|c|}
\hline $\begin{array}{l}\text { Depth } \\
\text { (m) }\end{array}$ & $\begin{array}{c}\text { Total } \\
\text { bacteria }\end{array}$ & $\begin{array}{l}\text { Bacterial } \\
\text { rods }\end{array}$ & $\begin{array}{c}\text { Large } \\
\text { protozoans }\end{array}$ & $\begin{array}{l}\text { Heterotrophic } \\
\text { micro- } \\
\text { flagellates }\end{array}$ & $\begin{array}{c}\text { Micro- } \\
\text { zooplankton }\end{array}$ & $\begin{array}{c}\text { Meso- } \\
\text { zooplankton }\end{array}$ & $\begin{array}{c}\text { Total } \\
\text { heterotrophs }\end{array}$ \\
\hline \multicolumn{8}{|l|}{ Station $M$} \\
\hline $2-12$ & 103.0 & 65.0 & 60.0 & 6.5 & 40.0 & 163.0 & 372.5 \\
\hline $12-24$ & 85.2 & 58.8 & 84.0 & 9.8 & 46.8 & 186.0 & 411.8 \\
\hline $24-36$ & 86.4 & 33.6 & 84.0 & 13.3 & 38.4 & 156.0 & 378.1 \\
\hline $36-48$ & 130.8 & 126.5 & 96.0 & 10.4 & 38.4 & 166.8 & 442.4 \\
\hline $48-60$ & 55.2 & 24.0 & 40.0 & 14.4 & 46.8 & 178.8 & 335.2 \\
\hline $60-76$ & 121.1 & 38.4 & 106.6 & 16.9 & 54.9 & 222.9 & 522.4 \\
\hline Total $\mathrm{mg} \mathrm{C} \mathrm{m}^{-2}$ & 581.7 & 346.3 & 470.6 & 71.3 & 265.3 & $1073.5(1210.7)$ & 2462.4 \\
\hline Total $\mathrm{mg} \mathrm{N} \mathrm{m}^{-2}$ & 116.3 & 69.3 & 94.1 & 14.3 & 60.4 & 244.5 & 529.6 \\
\hline \multicolumn{8}{|l|}{ Station F } \\
\hline $2-12$ & 352.0 & 322.0 & 590.0 & 33.1 & 55.0 & 58.0 & 1088.1 \\
\hline $12-24$ & 160.8 & 88.8 & 300.0 & 15.5 & 118.8 & 190.8 & 785.9 \\
\hline $24-36$ & 64.8 & 4.8 & 36.0 & 2.5 & 60.0 & 102.0 & 265.3 \\
\hline $36-48$ & 44.4 & 20.4 & 48.0 & 8.6 & 39.6 & 97.2 & 237.8 \\
\hline $48-60$ & 38.4 & 13.2 & 36.0 & 5.9 & 45.6 & 105.6 & 231.5 \\
\hline $60-96$ & 147.6 & 38.4 & 120.0 & 17.0 & 145.2 & 304,8 & 734.6 \\
\hline Total mg $\mathrm{C} \mathrm{m}^{-2}$ & 808.0 & 487.6 & 1130.0 & 82.6 & 464.2 & $858.4 \quad(885.3)$ & 3343.2 \\
\hline Total $\mathrm{mg} \mathrm{N} \mathrm{m}^{-2}$ & 161.6 & 97.5 & 226.0 & 16.5 & 105.7 & 195.5 & 705.3 \\
\hline \multicolumn{8}{|l|}{ Station E5 } \\
\hline $2-12$ & 38.0 & 33.0 & 18.0 & 6.9 & 137.0 & 290.0 & 489.9 \\
\hline $12-24$ & 94.8 & 80.4 & 96.0 & 18.2 & 121.2 & 334.8 & 665.0 \\
\hline $24-36$ & 42.0 & 25.2 & 10.8 & 2.8 & 25.2 & 242.4 & 323.2 \\
\hline $36-48$ & 43.2 & 32.4 & 6.0 & 4.6 & 2.4 & 168.0 & 224.2 \\
\hline $48-60$ & 30.0 & 16.8 & 10.8 & 3.1 & 46.8 & 134.4 & 225.1 \\
\hline $60-120$ & 192.0 & 84.0 & 46.0 & 17.4 & 124.0 & 908.0 & 1287.4 \\
\hline Total mg $\mathrm{C} \mathrm{m}^{-2}$ & 440.0 & 271.8 & 187.6 & 52.9 & 456.6 & $2077.6(2949.8)$ & 3214.7 \\
\hline Total $\mathrm{mg} \mathrm{N} \mathrm{m}{ }^{-2}$ & 88.0 & 54.4 & 37.5 & 10.6 & 104.0 & 473.3 & 713.4 \\
\hline
\end{tabular}


integrated standing stocks of each of the main categories of consumer organisms at the 3 stations.

For the purpose of the present work, meso- and micro-zooplankton have been considered to be exclusively herbivorous. This is clearly a major simplification, however, as a proportion of this biomass includes carnivores (e.g. chaetognaths) and many of the copepods themselves may be omnivorous (Paffenhöfer and Knowles, 1980).

We have also distinguished between some components of the trophic categories summarised by Holligan et al. (1984a). Thus although the total bacterial biomass represents an important component of the standing stocks of carbon in heterotrophic organisms, much as reported by Sorokin $(1975,1977,1978,1981)$ and Sieburth et al. (1978), large bacterial rods tend to be associated with the phytoplankton bloom in the euphotic zone whilst smaller rods and cocci predominate in deeper waters. There is a good deal of evidence that not all bacteria are actively growing under natural conditions, large bacteria associated with phytoplankton may primarily utilise photosynthetically produced dissolved organic carbon (Cole et al., 1982) whilst the cocci may represent metabolically inactive (dormant) or 'starved' forms (Stevenson, 1978; for review see van Es and Meyer-Reil, 1982) which can respond rapidly to organic enrichment (Vaccaro and Jannasch, 1966). We have therefore included bacterial rods as a separate column in Table 1.

Again, for the purpose of carbon flow estimates it has been useful to distinguish between the primarily bactivorous heterotrophic microflagellates (Fenchel, 1982a, b, c, d; Linley et al., 1983) and 'large Protozoa' which comprise dominantly Noctiluca at Station F and a mixed population of dinoflagellates, tintinnids and other ciliates at Stations M and E5. The standing stocks of each of these, as well as the microzooplankton and mesozooplankton (based partly on Holligan et al., 1984a) are summarised in Table 1 and show that the microheterotrophic community of protozoans and bacteria comprise as much as $46 \%$ of the total consumer carbon at mixed water station (M), $60 \%$ at frontal station (F) and $21 \%$ at the stratified station (E5).

The partitioning of nitrogen amongst the standing stocks of consumer organisms may be calculated from the distribution of carbon and the $\mathrm{C} / \mathrm{N}$ ratio of representatives of each of the major trophic categories as is shown in Table 1 . We have taken the $\mathrm{C} / \mathrm{N}$ ratio of bacteria as 5.0 (see also Fenchel and Blackburn, 1979) and have assumed this to apply to the Protozoa. In the case of the microzooplankton and mesozooplankton the $\mathrm{C} / \mathrm{N}$ ratio was found to vary with both depth and station. The $\mathrm{C} / \mathrm{N}$ ratios used in Table 1 are thus the mean of those directly determined from $\mathrm{CHN}$-analyses of the standing stocks at each depth interval. The $\mathrm{C} / \mathrm{N}$ ratio of the zooplankton community as a whole is 4.39 (Holligan et al., 1984a) compared with a $\mathrm{C} / \mathrm{N}$ ratio of between 6.0 and 8.5 for the primary producers (p. 113). From general principles, therefore, it is to be anticipated that approximately 1.3 to $1.8 \times$ as much carbon will be oxidised than nitrogen mineralised in the transformation of the products of primary production into consumer biomass.

\section{Carbon budget for pelagic consumer community}

\section{Consumption requirements}

One approach to an assessment of carbon flow through the heterotrophic community, and the extent to which primary production by the phytoplankton is likely to be capable of supporting consumer demands, is to combine literature data for the balanced energy equation for representative organisms with the integrated biomass values shown in Table 1 . The consumption requirements of the mesozooplankton, for example, have been estimated as $40 \%$ of the biomass per day, which is consistent with values for adult Calanus (e.g. Frost, 1972) whilst Calanus nauplii, representing the microzooplankton which is dominated by copepod nauplii, have been estimated to require $120 \%$ of their biomass $d^{-1}$ (e.g. Paffenhöfer, 1971; Fernandez, 1979). It should be noted, however, that these are maximal values determined at high food concentrations. At lower food levels, particularly those at Station E5, these values may overestimate zooplankton consumption considerably and may thus partly contribute to the mismatch between primary production by the phytoplankton and estimated carbon requirements by the heterotrophic community (p. 112). Dewey (1976) has made a detailed study of the components of the carbon budget of Noctiluca miliaris fed on phytoplankton cells. The mean values for ingested ration at a variety of concentrations of Dunaliella tertiolecta, Isochrysis galbana and Dunaliella euchlora at $20{ }^{\circ} \mathrm{C}$ was $113.9 \%$ of the body carbon $\mathrm{d}^{-1}$. Since the larger Protozoa were dominated by Noctiluca at Station $F$, this value has been applied to the whole of the 'large Protozoa' (Table 1).

Values for the estimated consumption requirements of the meso- and microzooplankton, as well as the 'large Protozoa' are summarised in Table 2. From this it is evident that carbon flow to the larger herbivores could amount to approximately $22.5 \%$ in the mixed water station (M), $18.1 \%$ at frontal station (F) and as high as $44.2 \%$ in the stratified water station (E5). Carbon flow to the herbivorous Protozoa is likely to range from $6.9 \%$ of total heterotrophic consumption at 
Table 2. Components of carbon flow through heterotrophic communities at mixed water station (M), frontal station (F) and stratified water station (E5). Estimates based on standing stocks ( $\mathrm{mg} \mathrm{C} \mathrm{m}^{-2}$; see Table 1) and literature values for balanced energy

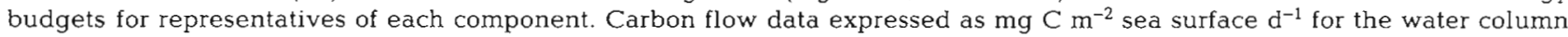
down to the sea bed, as well as a percentage of total estimated heterotrophic consumer demand

\begin{tabular}{|c|c|c|c|c|c|c|}
\hline \multirow{3}{*}{$\begin{array}{l}\text { Total heterothrophic } \\
\text { requirement } \\
\left(\mathrm{mgC} \mathrm{m}^{-2} \mathrm{~d}^{-1}\right)\end{array}$} & \multicolumn{2}{|c|}{ Station $M$} & \multicolumn{2}{|c|}{ Station F } & \multicolumn{2}{|c|}{ Station E5 } \\
\hline & $\left(\mathrm{mgC} \mathrm{m}^{-2} \mathrm{~d}^{-1}\right)$ & $\%$ & $\left(\mathrm{mgC} \mathrm{m}^{-2} \mathrm{~d}^{-1}\right)$ & $\%$ & $\left(m g C m^{-2} d^{-1}\right)$ & $\%$ \\
\hline & 3323.7 & 100 & 4989.4 & 100 & 3118.4 & 100 \\
\hline \multicolumn{7}{|l|}{ Microzooplankton } \\
\hline Biomass & 265.3 & - & 464.2 & - & 456.6 & - \\
\hline Consumption & 318.4 & 9.6 & 557.0 & 11.2 & 547.9 & 17.6 \\
\hline Production & 79.6 & 2.4 & 139.3 & 2.8 & 137.0 & 4.4 \\
\hline Respiration & 159.2 & 4.8 & 278.5 & 5.6 & 274.0 & 8.8 \\
\hline Faeces & 79.6 & 2.4 & 139.3 & 2.8 & 137.0 & 4.4 \\
\hline \multicolumn{7}{|l|}{ Mesozooplankton } \\
\hline Biomass & 1073.5 & - & 858.4 & - & 2077.6 & - \\
\hline Consumption & 429.4 & 12.9 & 343.4 & 6.9 & 831.0 & 26.6 \\
\hline Production & 107.4 & 3.2 & 85.8 & 1.7 & 207.8 & 6.7 \\
\hline Respiration & 214.7 & 6.5 & 171.7 & 3.4 & 415.5 & 13.3 \\
\hline Faeces & 107.4 & 3.2 & 85.8 & 1.7 & 207.8 & 6.7 \\
\hline \multicolumn{7}{|l|}{ Large Protozoa } \\
\hline Biomass & 490.6 & - & 1130.0 & - & 187.6 & - \\
\hline Consumption & 558.8 & 16.8 & 1287.1 & 25.8 & 213.7 & 6.9 \\
\hline Production & 165.3 & 5.0 & 380.8 & 7.6 & 63.2 & 2.0 \\
\hline Respiration & 131.5 & 4.0 & 302.8 & 6.1 & 50.3 & 1.6 \\
\hline \multicolumn{7}{|l|}{ Bacteria } \\
\hline Biomass & 581.7 & - & 808.0 & - & 440.0 & - \\
\hline Consumption & 2017.1 & 60.6 & 2801.9 & 56.2 & 1525.8 & 48.9 \\
\hline Production & 625.3 & 18.8 & 868.6 & 17.4 & 473 & 15.2 \\
\hline Respiration (+ U) & 1391.8 & 41.9 & 1933.3 & 38.7 & 1052.8 & 33.8 \\
\hline \multicolumn{7}{|l|}{ Microflagellates } \\
\hline Biomass & 71.4 & - & 82.6 & - & 52.9 & - \\
\hline Consumption & 606.9 & 18.3 & 702.1 & 14.1 & 449.7 & 14.4 \\
\hline Production & 212.4 & 6.4 & 245.8 & 4.9 & 157.4 & 5.0 \\
\hline Respiration $(+U)$ & 394.5 & 11.9 & 456.4 & 9.1 & 292.3 & 9.4 \\
\hline
\end{tabular}

Station E5 to $16.8 \%$ at Station $M$ and $25.8 \%$ at Station F. Total carbon flow to the herbivores could thus amount to approximately $39.3 \%$ of the estimated carbon requirements of the consumer community as a whole at Station M, $43.9 \%$ at Station F and $51.1 \%$ at Station E5.

Estimation of the consumption requirements of bacteria is complicated by scarcity of information on the proportion of the standing stocks which are actually heterotrophic (p. 112). Linley et al. (1983; see also Newell et al., 1981) have estimated carbon production and consumption requirements of bacteria based on batch cultures in phytoplankton debris at similar concentrations to those occurring in dense Gyrodinium blooms in surface waters. They report a mean bacterial production of $80.76 \pm 4.8 \mathrm{mg} \mathrm{C} \mathrm{m}^{-3} \mathrm{~d}^{-1}$ and a mean P/ $\mathrm{B}$ of $2.15 \pm 0.13$ which is equivalent to a generation time of about $20 \mathrm{~h}$. This value for production is very similar to the mean of maximal values for bacterial production cited from the literature by Newell and
Christian (1981) of $75 \mathrm{mg} \mathrm{C} \mathrm{m}^{-3} \mathrm{~d}^{-1}$ and may well apply to bacterial production by large rods associated with phytoplankton in productive coastal waters. However, most authors have reported that very low rates of bacterial production, approaching zero $\mathrm{mg} \mathrm{C} \mathrm{m}^{-3} \mathrm{~d}^{-1}$, can occur under natural conditions, implying that a variable proportion of the bacterial standing stocks are metabolically active. Literature values from a variety of marine environments suggest that 10 to $60 \%$ of bacteria are active (for review see van Es and MeyerReil, 1982). The mean of all the values cited from the literature by Newell and Christian (1981) is $39.1 \mathrm{mg}$ $C \mathrm{~m}^{-3} \mathrm{~d}^{-1}$ or about half the $P_{\max }$ cited above. This implies that, as reported by Fuhrman and Azam (1982) on a basis of thymidine incorporation, about half the bacteria are actively growing and that the $\mathrm{P} / \mathrm{B}$ ratio for the population as a whole should be half that of actively growing cultures; that is, a P/B of 1.075 corresponding to a generation time of approximately $33 \mathrm{~h}$. Accordingly, bacterial production values cited in 
Table 2 have been estimated from the biomass using a $\mathrm{P} / \mathrm{B}$ ratio of 1.075 .

Although we have found a $\mathrm{P} / \mathrm{C}$ ratio of only 0.1 to 0.15 for bacteria utilising detrital material which is poor in nitrogen (Newell, 1983), a higher carbon conversion efficiency of up to 0.37 has been obtained on natural detrital substrates with a lower $\mathrm{C} / \mathrm{N}$ ratio (Newell, 1983; Newell et al., 1983). Again, there is a good deal of evidence that bacterial incorporation of photosynthetically produced dissolved organic carbon (PDOC), which on average accounts for approximately $30 \%$ of primary production (Larsson and Hagström, 1982), may be achieved with an efficiency of 50 to $80 \%$ (for review, see Joint and Morris, 1982; Newell and Field, 1983b). For the purpose of estimating carbon flow through the microheterotrophic decomposer community based on phytoplankton, therefore, a $\mathrm{P} / \mathrm{C}$ ratio of 0.65 has been applied to the labile PDOC component comprising $30 \%$ of primary production and a lower value of 0.16 , representing the mean of all our daily estimates for conversion of the particulate components (Newell et al., 1981; Linley et al., 1983). Bacterial consumption requirements in Table 2 are thus calculated from $\mathrm{P} / 0.31$.

Finally, consumption (C) by the bactivorous heterotrophic microflagellates has recently been studied in some detail by Fenchel $(1982 a, b, c, d)$. Recalculation of his data suggests maximal consumption rates of $17 \times$ the body volume per day under well-fed conditions. This seems likely to apply to surface waters under bloom conditions when the biomass of bacteria is maximal (Linley et al., 1983) but we have assumed that the value for the water column as a whole, where bacterial biomass is considerably lower than in the surface waters, the consumption of the heterotrophic microflagellates is half of $C_{\max }$ or $8.5 \times$ the body weight per day in bacterial prey (see also Fenchel, 1980).

The results of each of these estimates of carbon consumption by the different trophic categories is summarised in Table 2 from which it is clear that at station (M) approximately $39 \%$ of the total carbon flow could enter the zooplankton (Crustacea and larger Protozoa) with an estimated $61 \%$ entering the bacteria. At Station F, $44 \%$ could enter the zooplankton and $56 \%$ the bacteria, whilst at Station E5 approximately $51 \%$ is estimated to enter the zooplankton and $49 \%$ the bacteria. It will also be noticed that flagellate consumption requirements account for 81 to $97 \%$ of the production of their bacterial prey. This is similar to estimates made for surface waters (Linley et al., 1983) and suggests that the standing stocks of bacteria are likely to be held more-or-less constant by the grazing of the heterotrophic microflagellates (see also Pomeroy and Johannes, 1968; Sieburth et al., 1978; Haas and Webb, 1979; Hollibaugh et al., 1980; Fenchel, 1982a,b,c,d).

\section{Carbon flow through the heterotrophic community}

Values for each of the components of the balanced energy equation for the different trophic groups at mixed water station (M), frontal station (F) and stratified water station (E5) are also summarised in Table 2. At Station M the micro- and mesozooplankton could together account for as much as $22.5 \%$ of carbon flow and contribute $5.6 \%$ as faeces. Bacteria could potentially account for approximately $60.6 \%$ of carbon consumption, leaving a residual of approximately $17 \%$ which could be exploited by the large Protozoa.

These relationships for Station $M$ are summarised in Fig. 1, whilst similar data for Station $F$ and Station E5

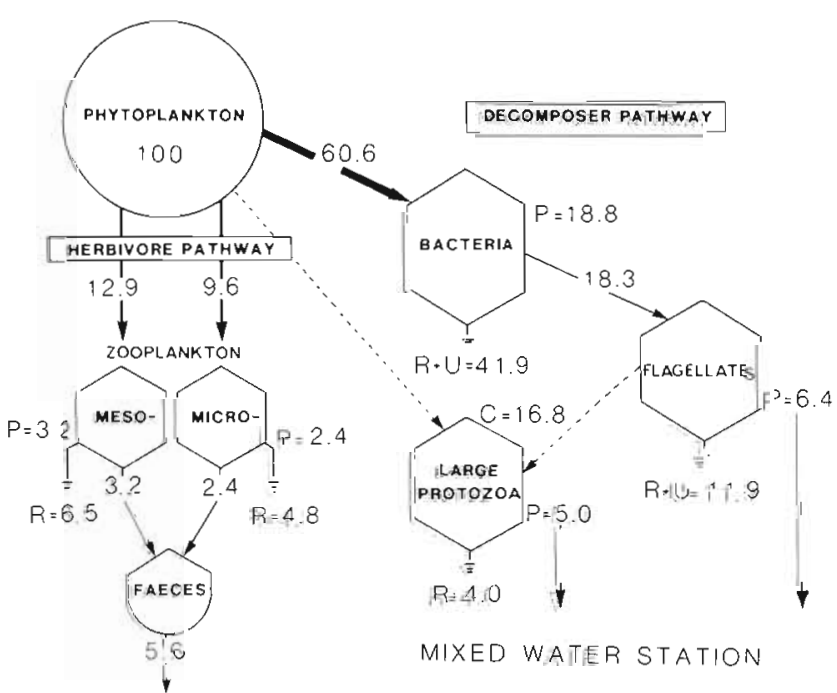

Fig. 1. Net carbon budget estimated from biomass data of the components of a plankton community at a mixed water station $(M)$ in the western English Channel. All values expressed as percentage of total carbon flow through the consumer community obtained from component biomass and balanced carbon budgets of the consumers (Consumption $=$ Production + Respiration + Faeces + Urine). For purpose of estimations all components, including bacteria, have been assumed to be actively heterotrophic. Compiled from Table 2

are shown in Table 2. The diagram shows net flow during the decomposition phase of a phytoplankton bloom rather than the actual pathways of carbon flow through the community in oligotrophic waters or during the early phase of a phytoplankton bloom. It is recognised, for example, that bacteria utilise organic matter released partly from the phytoplankton directly, partly from fragmented phytoplankton cells damaged during zooplankton grazing, and partly from the release of dissolved organic matter by the zooplankton and their faeces (Williams, 1981). Again, it is clear that the meso- and microzooplankton could potentially exploit both the protozoans and heterotrophic micro- 
flagellates, as well as excess bacterial production as a food resource. For simplicity, however, we have not included these alternative pathways into the carbon budget diagram; neither have we included pathways from copepod faeces, although these certainly lead ultimately to the decomposer pathway either in the water column or at the sediment-water interface.

Two main features emerge from these estimates of potential carbon flow through heterotrophic communities in mixed, frontal and stratified waters.

(1) As shown in Table 2, a depth-integrated carbon supply from primary producers of 3.1 to $4.9 \mathrm{~g}$ $\mathrm{C} \mathrm{m}{ }^{-2} \mathrm{~d}^{-1}$ would be required to sustain the carbon requirements of the consumer community. This carbon demand is higher than the gross primary production of 150 to $900 \mathrm{mg} \mathrm{C} \mathrm{m}^{-2} \mathrm{~d}^{-1}$ recorded at Station E5, 920 to $3600 \mathrm{mg} \mathrm{C} \mathrm{m}^{-2} \mathrm{~d}^{-1}$ at Station $\mathrm{F}$ and 700 to $3800 \mathrm{mg}$ $\mathrm{C} \mathrm{m}^{-2} \mathrm{~d}^{-1}$ at Station $\mathrm{M}$ by Holligan et al. (1984b). It is also higher than the average values for gross primary production of $540 \mathrm{mg} \mathrm{C} \mathrm{m} \mathrm{C} \mathrm{d}^{-1}$ (range 257.6 to $739.4 \mathrm{mg} \mathrm{C} \mathrm{m}^{-2} \mathrm{~d}^{-1}$ ) recorded in the Celtic Sea during July-August by Joint and Pomeroy (1983), and is higher than the 250 to $2000 \mathrm{mg} \mathrm{C} \mathrm{m}^{-2} \mathrm{~d}^{-1}$ reported for gross primary production in upwelling areas by Cushing (1971). This implies that even if experimental values for consumption are higher than those which occur under food-limited conditions in the open sea, the carbon consumption requirements of the heterotrophic community recorded in these waters during late August would need to be met from both production and biomass of senescent phytoplankton cells, and may thus account for the rapid decline and dissipation of the carbon at the end of a phytoplankton bloom at this time of the year.

Whether a comparable biomass of microheterotrophs occurs in the water column at these stations at other times of the year is not yet known. But the relatively low values commonly recorded for the primary production in these waters compared with the estimated consumer demands suggests that primary production alone could support the heterotrophic community only if a substantial proportion of the bacteria were not actively heterotrophic. From Table 2, for example, the consumption requirements of zooplankton and protozoans at Station $\mathrm{M}$ account for $1306.6 \mathrm{mg} \mathrm{C} \mathrm{m}^{-2} \mathrm{~d}^{-1}$. If we reduce this by half to allow for the effects of food concentration on consumption (see also p. 111) then the requirement becomes $653.3 \mathrm{mg} \mathrm{C} \mathrm{m}^{-2} \mathrm{~d}^{-1}$. If we take a gross primary production of $1000 \mathrm{mg} \mathrm{C} \mathrm{m}^{-2} \mathrm{~d}^{-1}$ as being made available to the consumers, then $1000-653.3=346.7 \mathrm{mg} \mathrm{C} \mathrm{m}{ }^{-2} \mathrm{~d}^{-1}$ would be available for plant respiration and bacterial consumption. The estimated bacterial carbon requirement is $2017.1 \mathrm{mg}$ $\mathrm{C} \mathrm{m}^{-2} \mathrm{~d}^{-1}$ at Station $\mathrm{M}$ (Table 2) so the amount available from primary production of $1000 \mathrm{mg} \mathrm{m}^{-2} \mathrm{~d}^{-1}$ could support only $17.2 \%$ of the bacteria without utilisation of biomass as well as production.

Clearly, primary production is often lower than this, and it is of interest to note that the proportion of active bacteria in the water column may range from $60 \%$ to as low as $10 \%$ (van Es and Meyer-Reil, 1982). Sieburth et al. (1977; see also Larsson and Hagström, 1982) have further reported that bacterial growth may occur only during the afternoon and evening. Carbon flow through the microheterotrophic community in pelagic systems may therefore be considerably lower than would be anticipated from the small cell size and relatively high biomass of these organisms. This may account for the very low values for bacterial production, approaching zero $\mathrm{mg} \mathrm{C} \mathrm{m} \mathrm{C}^{-2} \mathrm{~d}^{-1}$ which have commonly been reported under natural conditions (Newell and Christian, 1981; van Es and Meyer-Reil, 1982; Joint and Pomeroy, 1983).

(2) Under conditions of unrestricted carbon flow, where biomass as well as production by the phytoplankton is exploited, the proportion of carbon entering the decomposer pathway is similar at each of the stations, with approximately 49 to $60 \%$ of the total carbon entering the bacteria. These estimates for the community as a whole in general conform with those of Andrews and Williams (1971) who studied the uptake of ${ }^{14} \mathrm{C}$-labelled organic material by microheterotrophs in the size range 1 to $18 \mu \mathrm{m}$. They concluded that up to $50 \%$ of net photosynthetic production is taken up by the microheterotrophic community (see also Derenbach and Williams, 1974). Sorokin (1975, 1977, 1978, 1981) and Sorokin and Mikheev (1979) have estimated that as much as 70 to $80 \%$ of total energy flux in pelagic communities of the Peruvian upwelling system was associated with the bacteria, ciliates and zooflagellates (see also Gast and Horstmann, 1983; Linley et al., 1983). Our estimates of maximal carbon flow based on the biomass of microheterotrophs in the western English Channel are rather higher than the value of 25 to $30 \%$ of carbon from primary production estimated by Wiebe and Smith (1977) and Hagström et al. (1979) for surface waters because we have included all the consumer organisms from below the thermocline into our estimates of maximum heterotrophic demand, which is thus in addition to the $30 \%$ calculated for surface waters. As can be seen from Table 2, of the total carbon incorporated into the microheterotrophs, as much as 34 to $41 \%$ may be subsequently respired by the bacteria and a further 9 to $12 \%$ by the heterotrophic microflagellates.

From production values (Table 2) it can be seen that under conditions of maximal carbon flow, production by the meso- and microzooplankton would account for only $5.6 \%$ of carbon flow at mixed water station (M; see also Fig. 1), $4.5 \%$ at frontal station (F) and $11.1 \%$ 
at stratified station (E5). These values for the ecological efficiency (or 'transfer efficiency'; see Mann, 1982) through the larger zooplankton are relatively low. In general, it has been necessary to assume an ecological efficiency of at least $20 \%$ to account for fish yields in coastal waters (Steele, 1974). It is of interest, therefore, that inclusion of production by the microheterotrophs (indicated by downward arrows in Fig. 1) under conditions of unrestricted carbon flow, such as might occur in shallow water coastal situations, brings the ecological efficiency for the food web to levels which are to be anticipated from Steele's model (see also Mills and Fournier, 1979; Pomeroy, 1979). At Station M (Fig. 1) for example, inclusion of production by large Protozoa, flagellates and bacterial production not accounted for by the microflagellate consumption brings the ecological efficiency to $17.5 \%$, that at Station F to $20.3 \%$ and that at Station E5 to $18.9 \%$ (Table 2). The increased significance of the microheterotrophic decomposer pathway in shallow waters may thus be implicated in the well-known high secondary production which characterises coastal systems compared with offshore pelagic ones.

\section{Nitrogen budget for pelagic consumer community}

Estimates of nitrogen regeneration through the microheterotrophic community depend largely on that proportion of the bacterial population which is likely to be metabolically active, and on the duration of active growth under natural conditions. During the decomposition phase of a phytoplankton bloom, when biomass as well as production is available for exploitation, however, some values for nitrogen regeneration from the decomposition of phytoplankton cells with a known $\mathrm{C}$ : $\mathrm{N}$ ratio can be calculated on the assumption that the bacteria are actively heterotrophic.

\section{Estimates based on carbon flow}

The nitrogen actually consumed with the food can be calculated from the carbon consumption and the $\mathrm{C}: \mathrm{N}$ ratio of the food supply. The $\mathrm{C}: \mathrm{N}$ ratio of the phytoplankton forming the food of the herbivores was directly estimated to be 8.5 for the Gyrodinium population at Station F. At Stations $M$ and E5 a value of 6.0 was used as being more typical of the phytoplankton at these stations. The food of the large Protozoa was assumed to comprise partly heterotrophic microflagellates with a C : N ratio of 5.0 (p. 109) and partly phytoplankton with $\mathrm{C}: \mathrm{N}$ ratios of 6.0 to 8.5 , giving mean $\mathrm{C}: \mathrm{N}$ ratios of 5.5 to 6.75 . The bacteria forming the principal food of the heterotrophic microflagellates have a $\mathrm{C}: \mathrm{N}$ ratio of approximately 5.0 (Fenchel and Blackburn, 1979). These values, and the corresponding nitrogen consumption ( $\mathrm{mg} \mathrm{m} \mathrm{m}^{-2} \mathrm{~d}^{-1}$ ) for the principal components of the pelagic community at Stations $M, F$ and $\mathrm{E} 5$ are summarised in Table 3.

The nitrogen requirements of each group of the pelagic consumer community can be estimated from the balanced energy equation (p. 107) and knowledge of the $\mathrm{C}: \mathrm{N}$ ratio of the tissues and faeces. At Station $M$, for example, carbon consumption of the microzooplankton is $318.4 \mathrm{mg} \mathrm{C} \mathrm{m} \mathrm{C}^{-1}$ and faecal production is $79.6 \mathrm{mg} \mathrm{C} \mathrm{m}{ }^{-2} \mathrm{~d}^{-1}$ (Table 2). The $\mathrm{C}: \mathrm{N}$ ratio of fresh faeces is 8.0 (Turner and Ferrante, 1979), thus the nitrogen lost in the faeces is $10.0 \mathrm{mg} \mathrm{m}^{-2} \mathrm{~d}^{-1}$. Dissolved losses (U) are approximately the same as those in faeces (E.D.S. Corner, Marine Biological Association, Plymouth, pers. comm.) so nitrogen losses from (F) and (U) are $20.0 \mathrm{mg} \mathrm{N} \mathrm{m}^{-2} \mathrm{~d}^{-1}$. Carbon production is $79.6 \mathrm{mg} \mathrm{C} \mathrm{m}^{-2} \mathrm{~d}^{-1}$ (Table 2) and the mean $\mathrm{C}: \mathrm{N}$ ratio is 4.4 (Table 2) so the nitrogen equivalent of production (P) is $18.1 \mathrm{mg} \mathrm{N} \mathrm{m} \mathrm{m}^{-2} \mathrm{~d}^{-1}$. Total nitrogen requirements $(P+F+U)$ thus equal $38.1 \mathrm{mg} \mathrm{N}$ $\mathrm{m}^{-2} \mathrm{~d}^{-1}$ whilst the actual consumption (Table 3) was $53.1 \mathrm{mg} \mathrm{N} \mathrm{m}^{-2} \mathrm{~d}^{-1}$

In much the same way the carbon consumption of the mesozooplankton at Station $M$ was $429.4 \mathrm{mg} \mathrm{C}$ $\mathrm{m}^{-2} \mathrm{~d}^{-1}$ and faecal production at an absorption efficiency of $75 \%$ is $107.4 \mathrm{mg} \mathrm{C} \mathrm{m} \mathrm{C}^{-2} \mathrm{~d}^{-1}$ (Table 2). The $\mathrm{C}: \mathrm{N}$ ratio of the faeces is 8.0 so nitrogen losses in the faeces is $13.4 \mathrm{mg} \mathrm{N} \mathrm{m}^{-2} \mathrm{~d}^{-1}$. Dissolved losses (U) of $13.4 \mathrm{mg} \mathrm{N} \mathrm{m}^{-2} \mathrm{~d}^{-1}$ then give a total loss of $26.8 \mathrm{mg} \mathrm{N}$ $\mathrm{m}^{-2} \mathrm{~d}^{-1}$. Since production $(P)$ is $107.4 \mathrm{mg} \mathrm{C} \mathrm{m}^{-2} \mathrm{~d}^{-1}$ (Table 2) and the mean $\mathrm{C}: \mathrm{N}$ ratio of the tissues is 4.4 (Table 2), the nitrogen incorporated into production by the mesozooplankton is $24.4 \mathrm{mg} \mathrm{N} \mathrm{m}^{-2} \mathrm{~d}^{-1}$. Total nitrogen requirements $(\mathrm{P}+\mathrm{F}+\mathrm{U})$ thus equal $51.2 \mathrm{mg} \mathrm{N}$ $\mathrm{m}^{-2} \mathrm{~d}^{-1}$ compared with an ingested nitrogen of $71.6 \mathrm{mg} \mathrm{N} \mathrm{m}^{-2} \mathrm{~d}^{-1}$ (Table 3). The calculated nitrogen ingested with the food thus exceeds the nitrogen required for production in both microzooplankton and mesozooplankton at Station $M$ and similar results are obtained for Stations F and E5 (Table 3).

Calculations for bacteria and protozoans have been made as follows. At Station $M$, for example, bacterial consumption is $2017.1 \mathrm{mg} \mathrm{C} \mathrm{m} \mathrm{m}^{-2} \mathrm{~d}^{-1}$ (Table 2) and assuming the bacteria are responsible for the decomposition of phytoplankton cells with a $C: N$ ratio of 6.0 , the nitrogen consumption is $336.2 \mathrm{mg} \mathrm{N} \mathrm{m} \mathrm{m}^{-2} \mathrm{~d}^{-1}$ (Table 3). Production is $625.3 \mathrm{mg} \mathrm{C} \mathrm{m} \mathrm{C}^{-2} \mathrm{~d}^{-1}$ (Table 2) and the $\mathrm{C}: \mathrm{N}$ ratio is 5.0 , so the nitrogen channelled into production is $125.1 \mathrm{mg} \mathrm{N} \mathrm{m}^{-2} \mathrm{~d}^{-1}$. Mineralisation through the bacteria during the decomposition of phytoplankton cells is thus likely to be $336.2-125.1=$ $211.1 \mathrm{mg} \mathrm{N} \mathrm{m}^{-2} \mathrm{~d}^{-1}$ or $62.8 \%$ of the nitrogen supplied. Again, carbon consumption by the heterotrophic 
Table 3 . The estimated nitrogen entering consumers during phytoplankton decomposition and that released by the heterotrophic community. Values for nitrogen consumption $\left(\mathrm{C}_{\mathrm{N}}\right)$ by zooplankton and bacteria based on a $\mathrm{C} / \mathrm{N}$ ratio for phytoplankton of 6.0 at Stations $M$ and E5 and of 8.5 at Station F. A C/N ratio for bacteria of 5.0 was used to estimate nitrogen ingestion by the bactivorous microflagellates, whilst the diet of 'large Protozoa' was assumed to comprise the mean of the $\mathrm{C} / \mathrm{N}$ ratios of phytoplankton and flagellates at each station. Nitrogen losses have been estimated for the zooplankton from the sum of values for faecal $\left(F_{N}\right)$ and urinary $\left(U_{N}\right)$ losses where $C_{N}=P_{N}+F_{N}+U_{N}$ (see also p. 113); those for heterotrophic microorganisms (protozoans, flagellates and bacteria) have been estimated from the difference between estimated nitrogen consumption $\left(\mathrm{C}_{\mathrm{N}}\right)$ and production $\left(\mathrm{P}_{\mathrm{N}}\right)$. Nitrogen losses as \% of $\mathrm{C}_{\mathrm{N}}$ are also shown

\begin{tabular}{|c|c|c|c|c|}
\hline \multirow[t]{2}{*}{ Trophic category } & \multirow{2}{*}{$\begin{array}{l}\text { Consumption }\left(\mathrm{C}_{\mathrm{N}}\right) \\
\quad\left(\mathrm{mg} \mathrm{m}^{-2} \mathrm{~d}^{-1}\right)\end{array}$} & \multirow{2}{*}{$\begin{array}{l}\text { Production }\left(\mathrm{P}_{\mathrm{N}}\right) \\
\quad\left(\mathrm{mg} \mathrm{m} \mathrm{m}^{-2} \mathrm{~d}^{-1}\right)\end{array}$} & \multicolumn{2}{|c|}{ Losses } \\
\hline & & & $\left(m g m^{-2} d^{-1}\right)$ & $\%$ of $\mathrm{C}_{\mathrm{N}}$ \\
\hline \multicolumn{5}{|l|}{ Microzooplankton } \\
\hline Station $M$ & 53.1 & - & 19.9 & 37.5 \\
\hline Station F & 65.5 & - & 34.8 & 53.2 \\
\hline Station E5 & 91.3 & - & 34.3 & 37.5 \\
\hline \multicolumn{5}{|l|}{ Mesozooplankton } \\
\hline Station M & 71.6 & - & 26.9 & 37.5 \\
\hline Station F & 40.4 & - & 21.5 & 53.2 \\
\hline Station E5 & 138.5 & - & 52.0 & 37.4 \\
\hline \multicolumn{5}{|l|}{ Protozoa } \\
\hline Station $M$ & 101.6 & 33.1 & 68.5 & 67.4 \\
\hline Station F & 190.7 & 76.2 & 114.5 & 60.0 \\
\hline Station E5 & 38.9 & 12.6 & 26.3 & 67.5 \\
\hline \multicolumn{5}{|l|}{ Bacteria } \\
\hline Station M & 336.2 & 125.1 & 211.1 & 62.8 \\
\hline Station F & 329.6 & 173.7 & 155.9 & 47.3 \\
\hline Station E5 & 254.3 & 94.6 & 159.7 & 62.8 \\
\hline \multicolumn{5}{|l|}{$\mu \mathrm{m}$-Flagellates } \\
\hline Station $M$ & 121.4 & 42.5 & 78.9 & 65.0 \\
\hline Station $F$ & 140.4 & 49.2 & 91.2 & 65.0 \\
\hline Station E5 & 89.9 & 31.5 & 58.5 & 65.0 \\
\hline
\end{tabular}

Table 4. Estinated nitrogen regeneration through heterotrophic consumer communities at mixed water station (M), frontal station $(F)$ and stratified water station (E5). Values are expressed as $\mathrm{mg} \mathrm{N} \mathrm{m}^{-2}$ of sea surface $\mathrm{d}^{-1}$ at each station and also as a percentage of total nitrogen flow to the consumers during the decomposition of phytoplankton

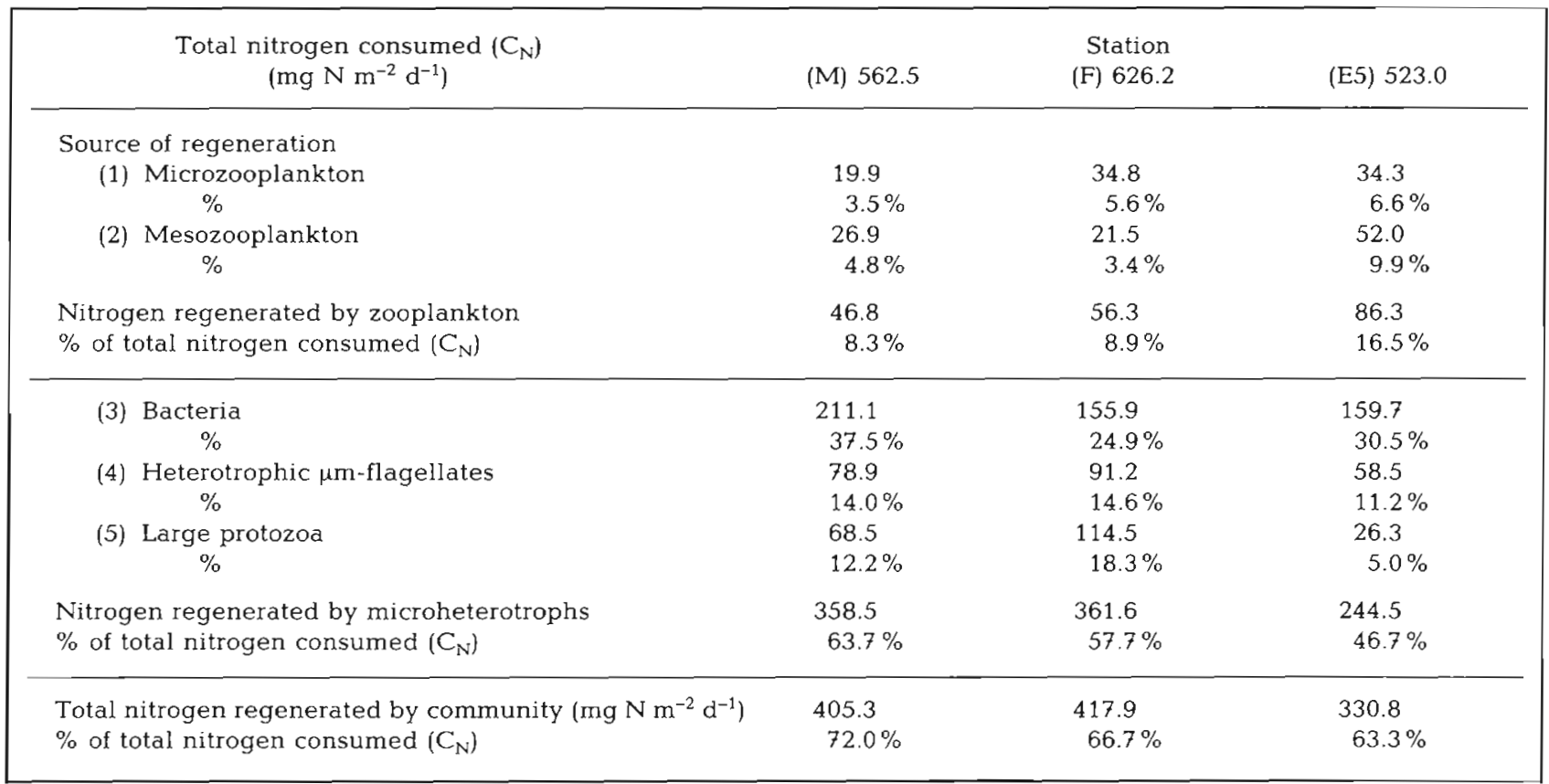


microflagellates at Station $\mathrm{M}$ was $606.9 \mathrm{mg} \mathrm{C} \mathrm{m}^{-2} \mathrm{~d}^{-1}$ and with a $\mathrm{C}: \mathrm{N}$ ratio of their bacterial prey of 5.0 , nitrogen consumption is $121.4 \mathrm{mg} \mathrm{N} \mathrm{m}^{-2} \mathrm{~d}^{-1}$ (Table 3). Production is $212.4 \mathrm{mg} \mathrm{C} \mathrm{m} \mathrm{m}^{-2} \mathrm{~d}^{-1}$ (Table 2) and the $\mathrm{C}: \mathrm{N}$ ratio is 5.0, so the nitrogen equivalent of production by the heterotrophic microflagellates is $42.48 \mathrm{mg}$ $\mathrm{N} \mathrm{m}^{-2} \mathrm{~d}^{-1}$. The excess of consumption over nitrogen required for production is thus $121.4-42.48=$ $78.92 \mathrm{mg} \mathrm{N} \mathrm{m}^{-2} \mathrm{~d}^{-1}$ or $65 \%$ of the nitrogen ingested. Finally, carbon consumption by the large Protozoa is $558.8 \mathrm{mg} \mathrm{C} \mathrm{m} \mathrm{m}^{-2} \mathrm{~d}^{-1}$ and at a $\mathrm{C}: \mathrm{N}$ ratio of 5.5 the nitrogen consumed is $101.6 \mathrm{mg} \mathrm{N} \mathrm{m} \mathrm{m}^{-2} \mathrm{~d}^{-1}$ (Table 3 ). Production is $165.3 \mathrm{mg} \mathrm{C} \mathrm{m} \mathrm{m}^{-2} \mathrm{~d}^{-1}$ (Table 2) and at a C : $N$ ratio of 5.0 , the nitrogen equivalent of production is $33.06 \mathrm{mg} \mathrm{N} \mathrm{m}^{-2} \mathrm{~d}^{-1}$. Nitrogen losses by the large Protozoa are thus $101.6-33.06=68.54 \mathrm{mg} \mathrm{N} \mathrm{m}^{-2} \mathrm{~d}^{-1}$ or $67.4 \%$ of the nitrogen ingested. Similar rather high values of nitrogen regeneration by Protozoa have been recently reported by Gast and Horstmann (1983). They showed that an average of $0.3 \mu \mathrm{mol} \mathrm{N} \mathrm{g}^{-1}$ wet weight $\mathrm{h}^{-1}$ was regenerated by 19 species of marine ciliates including Euplotes vannus.

\section{Nitrogen flow through heterotrophic community}

Although it has been shown above that nitrogen regeneration could occur at several steps in the microheterotrophic food web, it is necessary to include the relative biomass of each of the heterotrophic components to calculate nitrogen flow through the community as a whole during the decomposition of phytoplankton cell debris. From Table 4 it can be seen that because the biomass of bacteria is greater than that of the microflagellates, the total nitrogen regeneration through the bacteria could be as much as 25 to $37 \%$ of nitrogen flow from the phytoplankton compared with 5 to $18 \%$ through the large Protozoa. The overall potential regeneration of nitrogen from the microheterotrophic community including the bactivorous microflagellates at each of the sampling stations is estimated to be $358.5 \mathrm{mg} \mathrm{N} \mathrm{m}^{-2} \mathrm{~d}^{-1}$ or approximately $64 \%$ of the total nitrogen flow through the heterotrophs at Station $\mathrm{M}, 361.6 \mathrm{mg} \mathrm{N} \mathrm{m}^{-2} \mathrm{~d}^{-1}$ or approximately $58 \%$ of nitrogen flow through the consumer community at Station $\mathrm{F}$, and $244.5 \mathrm{mg} \mathrm{N} \mathrm{m} \mathrm{m}^{-2} \mathrm{~d}^{-1}$ or approximately $47 \%$ of the total nitrogen flow through the consumers at Station E5. By comparison, the nitrogen estimated to be regenerated through the grazing zooplankton amounts to only 8 to $16 \%$ of nitrogen flow through the consumers from phytoplankton.

These values are consistent with the observations of Dagg et al. (1980) for the Peru upwelling system where larger zooplankton constituted less than $3 \%$ of the ambient excretory nitrogen daily. Our estimates for nitrogen regeneration by the larger zooplankton have also been confirmed by direct measurements of ammonia release by the micro- and mesozooplankton during the course of our biomass estimates (R.P. Harris, Marine Biological Association, Plymouth, pers. comm.). Total nitrogen regeneration through both the zooplankton and the microheterotrophs could thus amount to 63 to $72 \%$ of nitrogen supplied from the decomposition of a phytoplankton bloom.

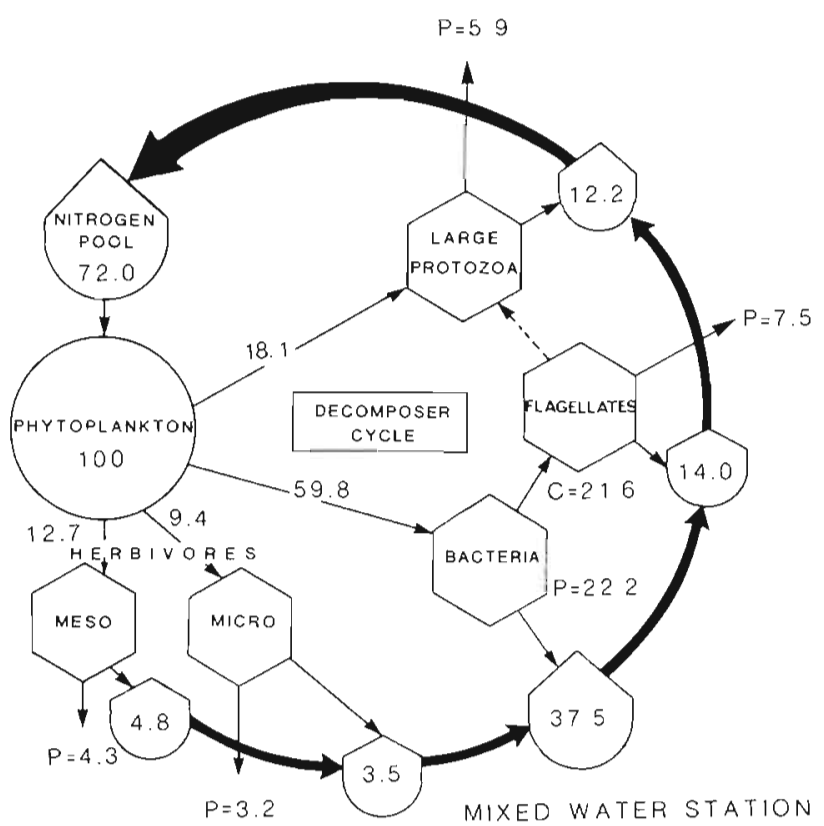

Fig. 2. Pathways of nitrogen regeneration through plankton community at mixed water station (M) in the western English Channel. Values expressed as percentage of total nitrogen flow through the consumer community during decomposition of a phytoplankton bloom

The nitrogen estimated to be regenerated by these components of the pelagic community at Station $M$ is shown in Fig. 2. It is important to point out, however, that under equilibrium conditions in stratified waters bacterial production may be supported mainly by photosynthetically-produced dissolved organic carbon (PDOC) which commonly constitutes $30 \%$ of primary production (Hagström et al., 1979; Cole et al., 1982; Larsson and Hagström, 1982), and by other sources of material such as refractory particulate organic carbon and faeces which have a relatively high $\mathrm{C}: \mathrm{N}$ ratio. The relative significance of bacteria and protozoans in nitrogen regeneration under these conditions may then be different from that estimated for the decomposition of phytoplankton cells. In a study which we have made on carbon and nitrogen flow in kelp communities, for example, where the $C: N$ ratio of the kelp detrital material is as high as 15.6 (Dieckmann, 1978), it is clear that nitrogen is incorporated by the bacteria with 
an efficiency of as much as $94 \%$ with little nitrogen regeneration at this first step in the decomposer food chain (Newell and Field, 1983a, b). In this case the larger zooplankton and the second step in the microbial food chain, from bacteria to heterotrophic microflagellates, may then represent the principal sources of nitrogen regeneration and this is likely to apply to other systems where the detrital source has a relatively low nitrogen content (see also Smith and Whitledge, 1977; Azam et al., 1983; Falkowski et al., 1983).

\section{CONCLUSIONS}

The results summarised above for the major components of the pelagic community off the western approaches to the English Channel during late August show that the microheterotrophic community of protozoans and bacteria comprise as much as $46 \%$ of the total consumer carbon at mixed water station (M), $60 \%$ at frontal station (F) and $21 \%$ at a deeper stratified water station (E5). These estimates of the biomass of pelagic consumers confirm those of other workers (Sorokin, 1975, 1977, 1978, 1981; Sieburth et al., 1978). They have then been combined with literature values for the carbon budgets of representatives of each of the major components of the heterotrophic community to arrive at an estimate of carbon flow through the consumer community as a whole.

A main feature which emerges from such estimates is that, as shown in Table 2, a depth-integrated carbon supply from primary production of 3.1 to $4.9 \mathrm{~g} \mathrm{C}$ $\mathrm{m}^{-2} \mathrm{~d}^{-1}$ would be required to sustain the carbon requirements of the consumer community if all components were actively heterotrophic. This carbon demand is much higher than the average gross primary production of 700 to $1000 \mathrm{mg} \mathrm{C} \mathrm{m} \mathrm{m}^{-2} \mathrm{~d}^{-1}$ reported for this and similar sea area(s) (Cushing, 1971; Joint and Pomeroy, 1983; Holligan et al., 1984b) and suggests that the carbon consumption requirements of the heterotrophic community recorded in these waters during late August would need to be met from both production and biomass of senescent phytoplankton cells. This may account for the rapid decline and dissipation of the carbon at the end of phytoplankton blooms at this time of the year.

It is suggested that in other sea areas, or at other seasons when consumer demands are met solely from primary production, a gross primary production of $1000 \mathrm{mg} \mathrm{C} \mathrm{m}{ }^{-2} \mathrm{~d}^{-1}$ could support the larger zooplankton and only $17 \%$ of the bacteria in an actively heterotrophic state. It is of interest, therefore, that most recent estimates suggest that the proportion of active bacteria in the water column under natural conditions may range from $60 \%$ to as low as $10 \%$ (van Es and
Meyer-Reil, 1982). Carbon flow through the microheterotrophic community in pelagic systems may therefore be considerably lower than would be anticipated from the small cell size and relatively high biomass of these organisms. This may account for the low values for bacterial production, approaching zero mg $\mathrm{C} \mathrm{m}^{-2} \mathrm{~d}^{-1}$ which have commonly been reported under natural conditions (Newell and Christian, 1981; van Es and Meyer-Reil, 1982; Joint and Pomeroy, 1983).

Under other conditions, where biomass as well as production by the phytoplankton is exploited, however, as much as 50 to $60 \%$ of total carbon flow may enter the bacteria. These values in general conform with those estimated from the uptake of ${ }^{14} \mathrm{C}$-labelled organic material (Andrews and Williams, 1971; Wiebe and Smith, 1977; Hagström, 1979) but are rather lower than the 70 to $80 \%$ of total energy flux estimated for the Peruvian upwelling system by Sorokin $(1975,1977$, 1978, 1981; Sorokin and Mikheev, 1979). Of the material entering the microheterotrophic pathway, our estimates suggest that as much as 34 to $41 \%$ may be subsequently respired by the bacteria and a further 9 to $12 \%$ by the heterotrophic microflagellates. In much the same way, estimates of nitrogen flow through the community suggest that nitrogen regeneration by the microheterotrophs during the decomposition of phytoplankton may amount to as much as 47 to $64 \%$ of nitrogen entering the consumer community.

The total flux of carbon and nitrogen estimated for the pelagic communities during the decomposition of phytoplankton is summarised in Table 5 . These values are quite similar to the estimates by Walsh et al. (1978) that $54 \%$ of the nitrogen requirements for primary production on the Atlantic Coastal Shelf may be supplied by regeneration through the zooplankton, bacteria and benthos, although it is rather higher than the corresponding value of $37 \%$ made recently by Harrison et al. (1983) for the mid-Atlantic Bight. Our estimates of carbon and nitrogen flux also closely resemble those recorded from the decomposition of sedimented phytoplankton from shallow waters by Billen (1978) and Nixon et al. (1976).

These estimates suggest that regeneration of nitrogen by the pelagic heterotrophic community could be of significance in supporting further primary production after the decomposition of phytoplankton blooms in shallow water situations (see also Harrison, 1978; Olsen, 1980; Paasche and Kristiansen, 1982; Pomeroy et al, 1983). The estimated value of $405.3 \mathrm{mg} N$ $\mathrm{m}^{-2} \mathrm{~d}^{-1}$ which could be regenerated under conditions of maximal carbon flow by the heterotrophic community at Station $M$ down to $76 \mathrm{~m}$ (Table 5), for example, corresponds to a regeneration of approximately $5.3 \mathrm{mg}$ $\mathrm{N} \mathrm{m}^{-3} \mathrm{~d}^{-1}$ whilst that at Station $\mathrm{F}$ (96 m depth) corres- 
Table 5. Estimated carbon oxidation and nitrogen regeneration by heterotrophic communities at Stations $M$, $F$ and E5 off the western English Channel during the decomposition phase of phytoplankton bloom. Compiled from Tables 2 and 4

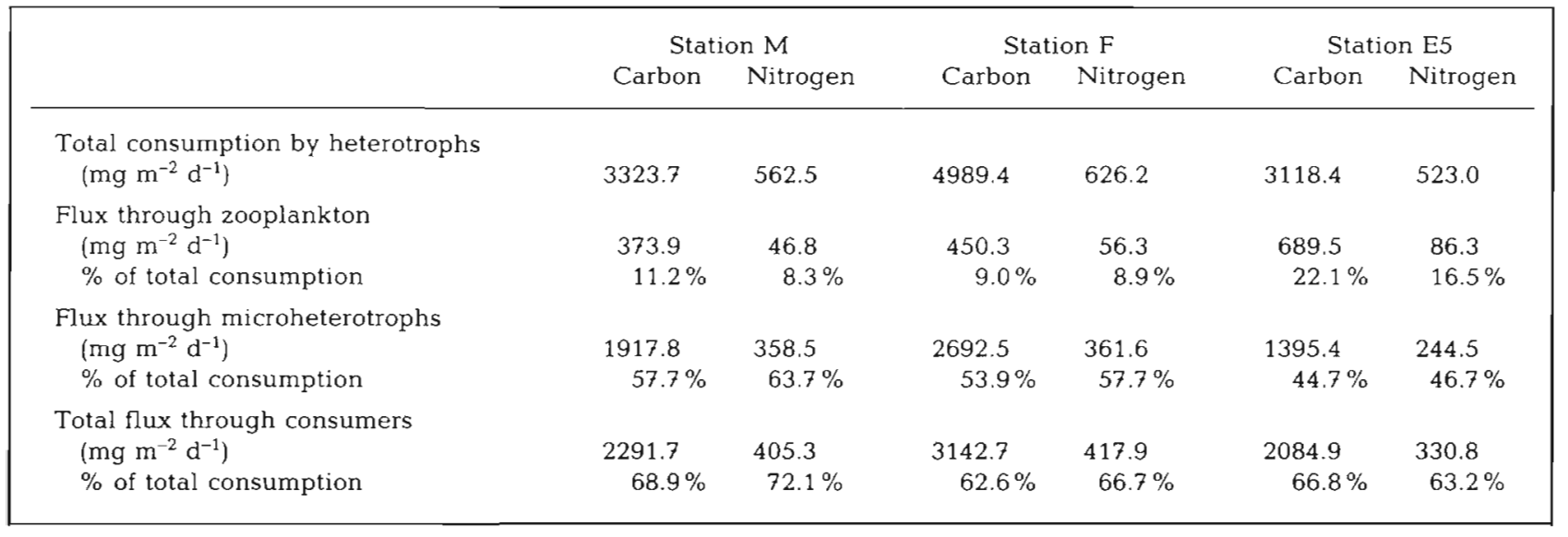

ponds to $4.4 \mathrm{mg} \mathrm{N} \mathrm{m}^{-3} \mathrm{~d}^{-1}$, and that at Station E5 (120 $\mathrm{m}$ depth) to $2.75 \mathrm{mg} \mathrm{N} \mathrm{m}^{-3} \mathrm{~d}^{-1}$. These values are somewhat higher than direct measurements of ammonia fluxes through the water column in the Southern California Bight in which regeneration was in the range of 0.31 to $3.07 \mathrm{mg} \mathrm{N} \mathrm{m}^{-3} \mathrm{~d}^{-1}$ (Harrison 1978) but are in general agreement with those recorded recently in shallow waters of the Celtic Sea, U.K. (N.J.P. Owens, Institute for Marine Environmental Research, Plymouth, pers. comm.; see also Pomeroy et al., 1983). In contrast, the relatively low proportion of bacteria which appear to be actively heterotrophic in steady-state situations suggests that nitrogen regeneration by bacteria and protozoans may be of less importance in offshore waters than in shallow coastal systems.

Acknowledgements. We are grateful for ship facilities aboard the R.V. 'Frederick Russell' which made this work possible, and for the help of Dr. M. I. Lucas and Ms. C. M. Weekley both on the cruise and in the laboratory. R. C. Newell is supported by funds from a Royal Society Senior Research Fellowship and Ms. E. A. S. Linley was in receipt of a NERC Postgraduate Fellowship for part of this study. The work was completed at the University of Cape Town during a visit funded by SANCOR. We are grateful for the helpful comments by Professor J. G. Field and other members of the Systems Analysis group of the Benguela Ecology Programme, and also for the detailed comments by Dr. R. P. Harris and Dr. P. M. Holligan of the Marine Biological Association, Plymouth, UK.

\section{LITERATURE CITED}

Andrews, P., Williams, P. J. le B. (1971). Heterotrophic utilisation of dissolved organic compounds in the sea. III. Measurements of the oxidation rates and concentrations of glucose and amino acids in seawater. J. mar. biol. Ass. U.K. $51: 111-125$

Azam, F., Fenchel, T., Field, J. G., Gray, J. S., Meyer-Reil, L.-A., Thingstad, F. (1983). The ecological role of the water-column microbes in the sea. Mar. Ecol. Prog. Ser. 10: 257-263

Billen, G. (1978). A budget of nitrogen recycling in North Sea sediments off the Belgian coast. Estuar. coast. mar. Sci. 7 $127-146$

Blackburn, T H., Henriksen, K. (1983). Nitrogen cycling in different types of sediments from Danish waters. Limnol. Oceanogr. 28: 477-493

Cole, J. J., Likens, G. E., Strayer, D. L. (1982). Photosynthetically produced dissolved organic carbon: an important carbon source for planktonic bacteria. Limnol. Oceanogr. 27 (6): $1080-1090$

Conover, R. J. (1966). Assimilation of organic matter by zooplankton. Limnol. Oceanogr. 11: 338-345

Cushing, D. H. (1971). A comparison of production in temperate seas and the upwelling areas. Trans. R. Soc. S. Afr. 40: $17-33$

Dagg, M., Cowles, T. J. (1982). Grazing by copepods in the Peru upwelling. Deep Sea Res. 29: 1A, 147

Dagg, M. J., Turner, J. T. (1982). The impact of zooplankton grazing on the phytoplankton of Georges Bank and the New York Bight. Can. J. Fish. aquat. Sci. 39: 979-990

Dagg, M., Cowles, T., Whitledge, T., Smith, S., Howe, S. Judkins, D. (1980). Grazing and excretion by zooplankton in the Peru upwelling system during April 1977. Deep Sea Res. 27: 43-59

Derenbach, J. B., Williams, P. J. le B. (1974). Autotrophic and bacterial production: fractionation of plankton populations by differential filtration of samples from the English Channel. Mar. Biol. 25: 263-269

Dewey, J. M. (1976). Rates of feeding, respiration and growth of the rotifer Brachionus plicatilis and the dinoflagellate Noctiluca miliaris in the laboratory. $\mathrm{Ph}$. D. thesis, University of Washington

Dieckmann, G. S. (1978). Aspects of growth and production of Laminaria pallida (Grev.) J. Ag. off the Cape Peninsula. M. Sc. thesis, University of Cape Town

Es, van F. B., Meyer-Reil, L. -A. (1982). Biomass and metabolic activity of heterotrophic marine bacteria. Adv microb. Ecol. 6: 111-170

Falkowski, P. G., Vidal, J., Hopkins, T. S., Rowe, G. T., Whitledge, T. E., Harrison, W. G. (1983). Summer nutrient dynamics in the Middle Atlantic Bight: primary production and utilization of phytoplankton carbon. J. Plankton Res. 5: 515-537 
Fenchel, T. (1980). Suspension feeding in ciliated Protozoa: relation between particle size selection and clearance. Limnol. Oceanogr. 25: 733-738

Fenchel, T. (1982a). Ecology of heterotrophic microflagellates. I. Some important forms and their functional morphology. Mar. Ecol. Prog. Ser. 8: 211-223

Fenchel, T. (1982b). Ecology of heterotrophic microflagellates. II. Bio-energetics and growth. Mar. Ecol. Prog. Ser. 8: $225-231$

Fenchel, T. (1982c). Ecology of heterotrophic microflagellates. III. Adaptations to heterogeneous environments. Mar. Ecol. Prog. Ser. 9: 24-33

Fenchel, T. (1982d). Ecology of heterotrophic microflagellates. IV. Quantitative occurrence and importance as consumers of bacteria. Mar. Ecol. Prog. Ser. 9: 35-42

Fenchel, T., Blackburn, T. H. (1979). Bacteria and mineral cycling. Academic Press, London

Fernandez, F. (1979). Nutrition studies of the nauplius larva of Calanus pacificus (Copepoda: Calanoida). Mar. Biol. 53: $131-147$

Frost, B. W. (1972). Effects of size and concentration of food particles on the feeding behaviour of the marine planktonic copepod, Calanus pacificus. Limnol. Oceanogr. 17: 805-819

Fuhrman, J. A., Azam, F. (1982). Thymidine incorporation as a measure of heterotrophic bacterioplankton production in marine surface waters: evaluation and field results. Mar. Biol. 66: 109-120

Gast, V., Horstmann, V. (1983). N-remineralisation of phytoand bacterioplankton by the marine ciliate Euplotes vannus. Mar. Ecol. Prog. Ser. 13: 55-60

Gerlach, S. A. (1978). Food chain relationships in subtidal silty sand marine sediments and the role of the meiofauna in stimulating bacterial productivity. Oecologia (Berl.) 33: $55-69$

Gieskes, W. W. C., Kraay, G. W., Baars, M. A. (1979). Current ${ }^{14} \mathrm{C}$ methods for measuring primary production: gross underestimates in oceanic waters. Neth. J. Sea Res. 13: $58-78$

Haas, L. W., Webb, K. L. (1979). Nutritional mode of several non-pigmented microflagellates from the York River Estuary Virginia. J. exp. mar. Biol. Ecol. 39: 125-134

Hagström, A., Larsson, U., Hörstedt, P., Normark, S. (1979) Frequency of dividing cells, a new approach to the determination of bacterial growth rates in aquatic environments. Appl. environ. Microbiol. 37: 805-812

Harrison, W. G. (1978). Experimental measurements of nitrogen remineralisation in coastal waters. Limnol. Oceanogr. 23: $684-694$

Harrison, W. G., Douglas, D., Falkowski, P., Rowe, G., Vidal, J. (1983). Summer nutrient dynamics of the Middle Atlantic Bight: nitrogen uptake and regeneration. J. Plankton Res. 5: 539-556

Hollibaugh, J. T., Carruthers, A. B., Fuhrman, J. A., Azam, F. (1980). Cycling of organic nitrogen in marine plankton communities studied in enclosed water columns. Mar. Biol. 59: 15-21

Holligan, P. M., Harris, R. P., Newell, R. C., Harbour, D. S., Head, R. N., Linley, E. A. S., Lucas, M. I., Tranter, P. R. G., Weekley, C. M. (1984a). Vertical distribution and partitioning of organic carbon in mixed, frontal and stratified waters of the English Channel. Mar. Ecol. Prog. Ser. 14; 111-127

Holligan, P. M., Williams, P. J. le B., Purdie, D., Harris, R. P. (1984b). Photosynthesis, respiration and nitrogen supply of plankton populations in stratified, frontal and tidally mixed shelf waters. Mar. Ecol. Prog. Ser., in press
Johnson, P. W., Sieburth, J. McN. (1979). Chroococcoid cyanobacteria in the sea: a ubiquitous and diverse phototrophic biomass. Limnol. Oceanogr. 24; 928-935

Johnson, P. W., Sieburth, J. McN. (1982). In situ morphology and occurrence of eucaryotic phototrophs of bacterial size in the picoplankton of estuarine and oceanic waters. J. Phycol. 18: 318-327

Joint, I. R., Pomeroy, A. J. (1983). Production of picoplankton and small nanoplankton in the Celtic Sea. Mar. Biol. 77 : $19-27$

Joint, I. R., Morris, R. J. (1982). The role of bacteria in the turnover of organic matter in the sea. Oceanogr. mar. Biol. A. Rev. 20: 65-118

Joiris, C., Billen, G., Lancelot, C., Daro, M. H., Mommaerts, J. P., Bertels, A., Bossicart, M., Nijs, J., Hecq, J. H. (1982). A budget of carbon cycling in the Belgian coastal zone: relative roles of zooplankton, bacterioplankton and benthos in the utilisation of primary production. Neth. J. Sea Res. 16: 260-275

Kremer, J. N., Nixon, S. W. (1978). A coastal marine ecosystem: simulation and analysis. Springer-Verlag, Berlin

La Roche, J. (1983). Ammonium regeneration: its contribution to phytoplankton nitrogen requirements in a eutrophic environment. Mar. Biol. 75: 231-240

Larsson, V., Hagström, A. (1982). Fractionated phytoplankton primary production, exudate release, and bacterial production in a Baltic eutrophication gradient. Mar. Biol. 67: $57-70$

Li, W. K. W., Subba Rao, D. V., Harrison, W. G., Smith, J. C., Cullen, J. J., Irwin, B., Platt, T. (1983). Autotrophic picoplankton in the tropical ocean. Science, N.Y. 219: 292-295

Linley, E. A. S., Newell, R. C., Lucas, M. I. (1983). Quantitative relationships between phytoplankton, bacteria and heterotrophic microflagellates in shelf waters. Mar. Ecol. Prog. Ser. 12: 77-89

Malone, T. C., Chervin, M. B. (1979). The production and fate of phytoplankton size fractions in the plume of the Hudson River, New York Bight. Limnol. Oceanogr. 24: 683-696

Mann, K. H. (1982). Ecology of coastal waters, a systems approach. Blackwell, Oxford

Mills, E. L., Fournier, R. O. (1979). Fish production and the marine ecosystems of the Scotian Shelf, Eastern Canada. Mar. Biol. 54: 101-108

Newell, R. C. (1983). The biological role of detritus in the marine environment. Proc. NATO Adv. Res. Inst. Bombannes May 1982. Plenum Press, New York (in press)

Newell, R. C., Field, J. G. (1983a). The contribution of bacteria and detritus to carbon and nitrogen flow in a benthic community. Mar. Biol. Lett. 4: 23-36

Newell, R. C. Field, J. G. (1983b). Relative flux of carbon and nitrogen in a kelp-dominated system. Mar. Biol. Lett. 4 : 249-257

Newell, R. C., Linley, E. A. S., Lucas, M. I. (1983). Microbial production and carbon conversion based on saltmarsh plant debris. Estuar. coast. Shelf Sci. (in press)

Newell, R. C., Lucas, M. I., Linley, E. A. S. (1981). Rate of degradation and efficiency of conversion of phytoplankton debris by marine micro-organisms. Mar. Ecol. Prog. Ser. 6 : 123-136

Newell, S. Y., Christian, R. R. (1981). Frequency of dividing cells as an estimator of bacterial productivity. Appl. environ. Microbiol. 42 (1): 23-31

Nixon, S. W., Oviatt, C. A., Hale, S. S. (1976). Nitrogen regeneration and the metabolism of coastal marine bottom communities. In: Anderson, J. M., MacFadyen, A. (ed.) The role of terrestrial and aquatic organisms in decom- 
position processes. Blackwell Scientific Publications, Oxford, p. 269-283

Olsen, R. J. (1980). Nitrate and ammonium uptake in Antarctic waters. Limnol. Oceanogr. 25: 1064-1074

Paasche, E., Kristiansen, S. (1982). Ammonium regeneration by microzooplankton in the Oslofjord. Mar. Biol. 69: 55-63

Paffenhöfer, G. A. (1971). Grazing and ingestion rates of nauplii, copepodites and adults of the marine planktonic copepod Calanus helgolandicus. Mar. Biol. 11: 286-298

Paffenhöfer, G. A. (1982). Grazing by copepods in the Peru upwelling. Deep Sea Res. 29: 1A, 145-147

Paffenhöfer, G. A., Knowles, S. C. (1980). Omnivorousness in marine planktonic copepods. J. Plankton Res. 2: 355-365

Petrusewicz, K., MacFadyen, A. (1970). Productivity of terrestrial animals, principles and methods. I.B.P. Handbook (13), Blackwell, Oxford

Platt, T., Subba Rao, D. V., Irwin, B. (1983). Photosynthesis of picoplankton in the oligotrophic ocean. Nature, Lond. 301 : $702-704$

Pomeroy, L. R. (1979). Secondary production mechanisms of continental shelf communities. In: Livingston, P. J. (ed.) Ecological processes coastal and marine systems. Plenum Press, New York, p. 163-186

Pomeroy, L. R., Johannes, R. E. (1968). Occurrence and respiration of ultra-plankton in the upper 500 metres of the ocean. Deep Sea Res. 51: 381-391

Rowe, G. T., Smith, K. L. (1977). Benthic-pelagic coupling in the mid-Atlantic Bight. In: Coull, B. C. (ed.) Ecology of marine benthos. University of South Carolina Press, Columbia, p. 55-65

Rowe, G. T., Clifford, C. H., Smith, K. L., Hamilton, P. L. (1975). Benthic nutrient regeneration and its coupling to primary productivity in coastal waters. Nature, Lond. 255: 215-217

Sheldon, R. W., Sutcliffe, W. H., Paranjape, M. A. (1977). Structure of pelagic food chain and relationship between plankton and fish production. J. Fish. Res. Bd Can. 34: $2344-2353$

Sieburth, J. McN. (1977). International Helgoland Symposium: Convener's report of the informal session on biomass and productivity of micro-organisms in planktonic ecosystems. Helgoländer wiss. Meeresunters. 30: $697-704$

Sieburth, J. McN., Smetacek, V., Lenz, J. (1978). Pelagic ecosystem structure: heterotrophic compartments of the plankton and their relationship to plankton size fractions. Limnol. Oceanogr. 23: 1256-1263
Smith, S. L., Whitledge, T. E. (1977). The role of zooplankton in the regeneration of nitrogen in a coastal upwelling system off northwest Africa. Deep Sea Res. 24: 49-56

Sorokin, Y I. (1975). Heterotrophic microplankton as a component of marine ecosystems. J. Obschei. biologii. M. 38: $716-730$

Sorokin, Y. I. (1977). The heterotrophic phase of plankton succession in the Japan Sea. Mar. Biol. 41: 107-117

Sorokin, Y I. (1978). Decomposition of organic matter and nutrient regeneration. In: Kinne, $O$. (ed.) Marine ecology, Vol. VI, Dynamics. Wiley, Chichester, p. 501-616

Sorokin, Y. I. (1981). Microheterotrophic organisms in marine ecosystems. In: Longhurst, A. R. (ed.) Analysis of marine ecosystems. Academic Press, New York, p. 293-342

Sorokin, Y. I., Mikheev, V. N. (1979). On characteristics of the Peruvian upwelling ecosystem. Hydrobiologia 62 (2): 165-198

Steele, J. H. (1974). The structure of marine ecosystems. Harvard University Press, Cambridge, Mass.

Stevenson, L. H. (1978). A case for bacterial dormancy in aquatic systems. Microb. Ecol. 4: 127-133

Turner, J. T., Ferrante, J. G. (1979). Zooplankton faecal pellets in aquatic ecosystems. Bioscience 29: 670-677

Vaccaro, R. F., Jannasch, H. W. (1966). Studies on heterotrophic activity in sea water based on glucose assimilation. Limnol. Oceanogr. 11: 596-607

Walsh, J. J. (1981). Shelf sea ecosystems. In: Longhurst, A. R. (ed.) Analysis of marine ecosystems. Academic Press, London, p. 159-196

Walsh, J. J., Whitledge, T. E., Barnevitz, F. W., Wirick, C. D., Howe, S. O., Esaias, W. E., Scott, J. T. (1978). Wind events and food chain dynamics within the New York Bight. Limnol. Oceanogr. 23: 659-683

Waterbury, J. B., Watson, S. W., Guillard, R. R. L., Brand, L. E. (1979). Widespread occurrence of a unicellular, marine planktonic cyanobacteria. Nature, Lond. 277: 293-294

Wiebe, W. J., Smith, D. F. (1977). Direct measurement of dissolved organic carbon release by phytoplankton and incorporation by microheterotrophs. Mar. Biol. 42: 213-223

Williams, P. J. le B. (1981). Incorporation of microheterotrophic processes into the classical paradigm of the planktonic food web. Kieler Meeresforsch. 5: 1-28

Winberg, G. C. (1956). Rate of metabolism and food requirements of fishes (Russ.). Belorussian State Univ., Minsk. (Transl. Ser. Fish. Res. Bd Can. 194) 